\title{
Krzysztof Natalli
}

Uniwersytet Ekonomiczny we Wrocławiu

e-mail: natalli@wp.pl

\section{METODY WYZNACZANIA FUNKCJI \\ WYNAGRODZEŃ ORAZ SZACOWANIA \\ OKRESU ZWROTU I STOPY ZWROTU \\ INDYWIDUALNYCH INWESTYCJI \\ W WYŻSZE WYKSZTALCENIE}

\section{METHODS OF ESTIMATION OF WAGE \\ FUNCTION, PERIOD OF RETURN \\ AND RATE OF RETURN OF INDIVIDUAL \\ INVESTMENTS IN HIGHER EDUCATION}

DOI: $10.15611 / \mathrm{e} 21.2016 .2 .03$

JEL Classification: I220

Streszczenie: Artykuł prezentuje metody, które były wykorzystywane przez innych badaczy (zarówno polskich, jak i przede wszystkim zagranicznych) do wyznaczania funkcji wynagrodzeń oraz szacowania okresu i stopy zwrotu z inwestycji w wyższe wykształcenie. Omawia również zalety i wady każdej z nich i podaje wnioski, które z takiego omówienia wynikają. Taka szczegółowa analiza i krytyka piśmiennictwa i badań z tego zakresu umożliwi zaproponowanie rozwiązań, które najlepiej nadają się do badania rentowności indywidualnej inwestycji w wyższe wykształcenie, co jest głównym celem badawczym artykułu. Autor prezentuje również mierniki, które najlepiej odpowiadają jednorazowemu charakterowi inwestycji w wyższe wykształcenie, a dotychczas nie były w tego typu badaniach wykorzystywane (MIRR, NPV, PI).

Słowa kluczowe: funkcja wynagrodzeń, okres zwrotu i stopa zwrotu z inwestycji w wyższe wykształcenie.

Summary: The main purpose of the paper is to present the methods used to estimate wage function, period of return and rate of return of individual investments in higher education. It should allow to show the disadvantages and advanteges of each of them and propose new solutions of calculating profitability of such investments.Aurhor presents measures that responds to the one-time nature of individual investments in higher education (MIRR, NPV, PI) and have been never used before for such researches.

Keywords: wage function, period of return and rate of return of individual investments in higher education. 


\section{Metody wyznaczania funkcji wynagrodzeń i pomiaru rentowności kształcenia}

Prekursorami badań rentowności kształcenia, czyli ilościowego ujmowania jego nakładów i efektów, byli w latach 50. i 60. XX wieku T.W. Schultz [1967] i J. Mincer [1958]. Pierwszy z nich zajął się szacowaniem okresu zwrotu z inwestycji w wykształcenie, a drugi wyznaczaniem funkcji wynagrodzeń i stopy zwrotu $z$ takiej inwestycji. Podstawą tych rozważań było założenie teorii kapitału ludzkiego mówiące, iż inwestycja w edukację powoduje wzrost wydajności pracy, a tym samym przekłada się na wyższe wynagrodzenie za wykonywaną pracę [Schultz 1971, s. 25]. Kolejni badacze, zajmujący się problematyką kapitału ludzkiego lub wpływem edukacji na sytuację jednostki na rynku pracy, korzystali z metod zaproponowanych przez wymienionych autorów (szczególnie $\mathrm{z}$ funkcji płac Mincera). W zależności jednak od dostępnych danych statystycznych, celu badania lub specyfiki danego kraju modyfikowali te metody tak, aby dostosować je do własnych potrzeb. Spowodowało to, że z jednej strony większość przeprowadzonych dotychczas badań jest w swojej głównej części oparta na tej samej koncepcji zaproponowanej przez Mincera, ale z drugiej strony ze względu na modyfikacje wprowadzone przez autorów zdecydowanie zróżnicowana. Utrudnia to oczywiście porównywanie wyników tych badań między sobą.

$\mathrm{W}$ poszczególnych badaniach różny był między innymi zakres uwzględnianych w danym badaniu kosztów związanych ze zdobyciem wyższego wykształcenia. W części badań za istotny uznano jedynie koszt alternatywny związany z utraconym wynagrodzeniem przez okres studiów. Osoby, które podejmują pracę po zdaniu matury, zaczynają osiągać dochody w wieku 19 lat, w przeciwieństwie do osób rozpoczynających pracę dopiero po ukończeniu studiów, czyli w wieku 24 lat. Oznacza to, że rezygnują w ten sposób z możliwości otrzymywania wynagrodzenia od 19 do 23 roku swojego życia, licząc na to, iż po ukończeniu studiów ich wynagrodzenie za pracę będzie na tyle wyższe od tego, które mogliby otrzymać, mając jedynie wykształcenie średnie, że ich decyzja o podjęciu studiów i opóźnieniu wejścia na rynek pracy okaże się opłacalna $\mathrm{z}$ finansowego punktu widzenia. W pozostałych badaniach do kosztów zdobycia wyższego wykształcenia zaliczono m.in.: koszty bezpośrednio związane ze studiami (np. czesne, pozostałe opłaty związane z podjęciem studiów, koszt zakupu podręczników itp.) oraz koszty pośrednio związane ze studiami (np. koszt wyżywienia, dojazdu na uczelnię, zamieszkania przez czas studiów). Do różnic pomiędzy poszczególnymi badaniami należy także zaliczyć uwzględnianie bądź pomijanie prawdopodobieństwa posiadania pracy w zależności od posiadanego poziomu wykształcenia (czyli de facto zagrożenia bezrobociem).

\subsection{Funkcja wynagrodzeń J. Mincera i jej modyfikacje}

Najczęściej wykorzystywaną metodą do badania wpływu wykształcenia na uzyskiwane wynagrodzenie jest funkcja płac Mincera i jej modyfikacje. W oryginalnej for- 
mie zaproponowanej przez Jacoba Mincera logarytmowana funkcja płac uwzględniała tylko liczbę lat kształcenia oraz składnik losowy nieskorelowany ze zmienną objaśnianą [Mincer 1974, s. 7-9]. Szybko została jednak rozbudowana o doświadczenie zawodowe mierzone latami pracy zawodowej [Mincer 1974, s. 11-20]. W praktyce najczęściej zastępuje się rzeczywiste doświadczenie zawodowe potencjalnym, czyli przyjmuje się, że doświadczenie zawodowe to różnica między wiekiem osoby a wiekiem ukończenia posiadanego przez nią poziomu wykształcenia. Takie uproszczenie wynika z trudności pozyskania danych statystycznych, w których oprócz wynagrodzeń i wykształcenia znajdowałyby się również informacje o rzeczywistym stażu zawodowym. Mincer założył, iż kolejne lata edukacji dają taki sam przyrost wynagrodzeń (bez rozróżniania poziomów i kierunków kształcenia) oraz że osoby z różnym wykształceniem mają identyczne szanse na podjęcie pracy i jednakowy wiek przejścia na emeryturę. Zauważył też, że inwestycja $\mathrm{w}$ edukację jest związana z ponoszeniem kosztów bezpośrednich (zaliczył do nich wydatki na materiały biurowe i książki) i pośrednich, do których zaliczył utracone wynagrodzenie przez dodatkowe lata nauki. W swoich szacunkach uwzględnił jedynie koszty pośrednie.

J. Mincer przy wykorzystaniu regresji wielorakiej z wykorzystaniem metody najmniejszych kwadratów oszacował następujące równanie:

$$
\operatorname{Ln}\left(Y_{i}\right)=a_{0}+a_{1} * S_{i}+a_{2} * X_{i}+a_{3}^{*} X_{i}^{2}+\varepsilon_{i},
$$

gdzie:

$\operatorname{Ln}\left(Y_{i}\right)$ - logarytmowane wynagrodzenie brutto,

$S_{i} \quad$ - lata kształcenia,

$X_{i} \quad$ - doświadczenie zawodowe w latach osoby $i$.

Szacowanymi współczynnikami były $a_{0}, a_{1}, a_{2} \mathrm{i} a_{3}$, a składnik losowy $\varepsilon_{i}$ uwzględniał pozostałe czynniki wpływające na płace, które nie zostały wyjaśnione przez pozostałe zmienne. Współczynnik $a_{1}$ według Mincera miał odpowiadać wielkości indywidualnej rentowności z kolejnych lat kształcenia. Jest to błędna interpretacja, choć powszechnie wykorzystywana w literaturze, gdyż nie można mówić o rentowności kształcenia bez uwzględnienia choćby kosztów takiej inwestycji. Współczynnik ten pozwala ewentualnie wyznaczyć procentowy wzrost wynagrodzeń w przypadku wydhużenia edukacji o kolejny rok. Autor założył, iż wzrost doświadczenia zawodowego prowadzi do wzrostu umiejętności i jednocześnie do utraty zdobytej w czasie kształcenia wiedzy. Oznacza to, że w miarę upływu lat pracy wynagrodzenia w coraz większym stopniu zależą od doświadczenia zawodowego, a w coraz mniejszym od zdobytego wykształcenia. Stąd właśnie wynika podniesienie doświadczenia zawodowego do kwadratu. Wykorzystanie zlogarytmowanego równania funkcji wynagrodzeń wynikało z założeń teorii kapitału ludzkiego, że rozkład logarytmiczno-normalny dobrze przybliża rozkład zarobków [Cichy, Malaga 2007, s. 19].

J. Mincer, wykorzystując powyższe równanie, przeprowadził badania korelacji między okresem kształcenia a otrzymywanym wynagrodzeniem na podstawie danych 
statystycznych z 1960 roku. Oszacował w ten sposób, iż indywidualna rentowność kształcenia wynosiła około $10 \%$ za każdy kolejny rok edukacji, a każdy dodatkowy rok stażu pracy przeciętnie przynosił wzrost wynagrodzeń w wysokości około $8 \%$. Potwierdzało to w jednoznaczny sposób postawioną przez niego tezę, że długość okresu kształcenia nie tylko dodatnio wpływa na wysokość otrzymywanego wynagrodzenia, ale także w miarę wzrostu doświadczenia zawodowego zależność ta przybiera na sile [Mincer 1974, s. 45-74].

Jednym z najważniejszych zarzutów stawianych metodzie zaproponowanej przez J. Mincera jest fakt, iż przyjęto w niej założenie, że każdy dodatkowy rok nauki daje identyczny przyrost wiedzy, a tym samym taki sam wzrost poziomu wynagrodzeń. Takie założenie jest nie tylko wątpliwe, ale może prowadzić wręcz do błędnych wniosków (np. osoba powtarzająca kilkakrotnie tę samą klasę po zakończeniu edukacji na poziomie średnim będzie miała taki sam okres kształcenia co osoba po studiach, a zgodnie z założeniami modelu powinno przynieść to identyczną rentowność z edukacji). Uzasadnione wydaje się więc zastosowanie modyfikacji zaproponowanej przez V. Steinera i C. Lauera, którzy zastąpili lata kształcenia uzyskanymi poziomami wykształcenia. Rozszerzyli oni metodę zaproponowaną przez Mincera, zastępując ujęcie ilościowe (lata kształcenia) podejściem jakościowym (poziomy wykształcenia), wyróżniając uniwersytety, wyższe szkoły zawodowe, szkoły średnie ogólne i zawodowe oraz gimnazjum. Funkcja zaproponowana przez Lauera i Steinera miała więc następująca postać [Lauer, Steiner 2001, s. 10]:

$L n$ (wynagrodzenie) $i=a_{0}+a_{1}{ }^{*}($ gimnazjum $) i+a_{2}{ }^{*}($ szkoła zawodowa $) i+$ $a_{3}{ }^{*}\left(\right.$ szkoła średnia)i $+a_{4}{ }^{*}$ (wyższa szkoła zawodowa) $i+a_{5}{ }^{*}$ (uniwersytet) $i+a_{6}$ *(doświadczenie zawodowe) $i+a_{7} *$ (doświadczenie zawodowe) $i^{2}+\varepsilon_{i}$.

Zastosowali oni w tym równaniu metodę zero-jedynkową, przyjmując, iż w przypadku osiągnięcia danego poziomu wykształcenia zmienna odpowiadająca za ten poziom przyjmuje wartość 1, a w przeciwnym przypadku wartość 0 . Analizę rozpoczęto od osób, które co najmniej ukończyły gimnazjum, zakładając dodatkowo, że zdobycie każdego z poziomów wykształcenia zajmuje standardowy okres. Pozwoliło to wyznaczyć wiek, w jakim powinna się znajdować konkretna osoba po ukończeniu danego poziomu wykształcenia. W ten sposób możliwe było wyliczenie doświadczenia zawodowego (traktowanego jako doświadczenie potencjalne) - od wieku danej osoby odejmowano standardowy okres kształcenia przewidziany dla danego poziomu wykształcenia oraz okres przed rozpoczęciem edukacji (standardowo 6 lat). Według autorów zastąpienie doświadczenia rzeczywistego potencjalnym nie wpływa w sposób istotny na wyliczenia rentowności. Przyjęto także założenie o normalności rozkładu składników losowych oraz braku ich autokorelacji i heteroskedastyczności tak, aby do wyliczeń funkcji móc wykorzystać metodę najmniejszych kwadratów. Pomimo braku potwierdzenia takiej hipotezy, dalsze badania (prowadzone między innymi przez A. Ammermullera i D. Domena) wykazały, że wykorzystanie uogólnionej metody najmniejszych kwadratów czy też wprowadzenie dodatkowych zmiennych do modelu (branża, wielkość przedsiębiorstwa, region) nie dają istotnych odchyleń od 
wyników opartych na klasycznym równaniu zaproponowanym przez C. Lauera i V. Steinera [Lauer, Steiner 2001, s. 7-9; Ammermuller, Dohmen 2004, s. 30]. Pozwala to uznać metodę zaproponowaną przez tych autorów za właściwą do zastosowania [Jarecki 2011, s. 108-110].

Badania przeprowadzone przez Lauera i Steinera należą do najbardziej cenionych w Europie. Informacje w nich wykorzystane pochodziły z danych zebranych przez instytut badawczy TNS Infratest Sozialforschung z lat 1984-1997. Ankietowano reprezentatywną próbę około 12000 osób w wieku 30-60 lat, zbierając informacje na temat ich wykształcenia, miesięcznych wynagrodzeń brutto za godzinę pracy oraz tygodniowego czasu pracy w godzinach. Pozwoliło to przeliczyć wynagrodzenia na pełen etat $\mathrm{z}$ wykorzystaniem deflatora indeksu cen konsumpcyjnych. Pominięto ryzyko bezrobocia, a do kosztów kształcenia zaliczono jedynie koszt alternatywny w postaci utraconych wynagrodzeń brutto przez okres edukacji [Lauer, Steiner 2001, s. 2-3].

Wyniki otrzymane przez C. Lauera i V. Steinera wskazywały, że najwyższą rentowność dawało ukończenie szkoły zawodowej (ok. 11\% dla mężczyzn i ok. 13\% dla kobiet), a najniższą uniwersytetu (niecałe $8 \%$ dla mężczyzn i ponad $9 \%$ dla kobiet). Większa rentowność dla kobiet została potwierdzona testem statystycznym na poziomie istotności $1 \%$ i może wynikać $\mathrm{z}$ faktu, iż w badaniu nie były uwzględnione osoby nieaktywne zawodowo i bezrobotne, z których większość w tych latach stanowiły kobiety. Obliczona rentowność dla tej płci była więc z tej przyczyny zawyżona. Według autorów kształcenie można uznać za opłacalne, w przypadku gdy roczna stopa zwrotu z takiej inwestycji przekracza 5\%, czyli stopę zwrotu z pozbawionej ryzyka inwestycji w obligacje państwowe [Lauer, Steiner 2001, s. 5-13].

Należy także wymienić inne znaczące badania nad rentownością kształcenia wykorzystujące funkcję wynagrodzeń zaproponowaną przez J. Mincera, przy wspomnianym jednak wcześniej zastrzeżeniu, iż pojęcie rentowności było w nich traktowane wyłącznie jako procentowy wzrost wynagrodzeń przy wydłużeniu edukacji o rok lub przy osiągnięciu kolejnego poziomu wykształcenia.

Najszersze badania międzynarodowe przedstawili G. Psacharopoulos i H. Patrinos, wyznaczając prywatną rentowność z inwestycji w wyższe wykształcenie dla 98 krajów w latach 1959-1989. Wyznaczona przez nich rentowność za każdy dodatkowy rok nauki wynosiła od 7,1\% w Europie i Afryce Północnej do 12\% w Ameryce Łacińskiej, przy przeciętnej dla całego świata na poziomie 9,7\% [Psacharopoulos, Patrinos 2002, s. 14].

Do wartych uwagi powinno się także zaliczyć badania przeprowadzone przez Kalpana Pai. Choć funkcja wynagrodzeń zaproponowana przez niego miała najprostszą postać uwzględniającą jedynie poziomy wykształcenia i potencjalne doświadczenie zawodowe, to dzięki wykorzystaniu obszernej bazy danych pochodzącej z Luxembourg Income Study (LIS) udało mu się wyznaczyć rentowność z kształcenia dla 10 krajów z różnych części świata w latach 1986-2000. Niewątpliwą zaletą danych pochodzących z LIS jest fakt, iż są one odpowiednio standaryzowane, aby umożliwić porównania międzypaństwowe [Kalpana 2008]. 
Należy także wspomnieć o badaniach przeprowadzonych przez D. Acemoglu i J. Angrista dla Stanów Zjednoczonych oraz Y. Bar-Ora wraz ze współpracownikami dla Kanady. Pierwsze z nich wykazało, że każdy dodatkowy rok kształcenia przynosi około 7,5-procentowy wzrost wynagrodzeń, a drugie wyliczyło rentowność dla całych studiów wyższych na poziomie około 30\% [Acemoglu, Angrist 1999; Bar-or, Burbidge, Magee, Robb 1995].

Nie wolno zapominać o wielu badaniach przeprowadzonych dla krajów należących do Unii Europejskiej. Do najważniejszych należy zaliczyć badania przeprowadzone przez C. Harmona, H. Oosterbeeka i I. Waltera dla 15 krajów należących do UE. Przeciętna rentowność oszacowana przez tych badaczy wyniosła 6,5\% [Harmon, Oosterbeek, Walter 2002]. Z kolei A. de la Fuente w swoim raporcie dla Komisji Europejskiej otrzymał roczną stopę zwrotu z kształcenia na poziomie 6,2\% [De la Fuente 2003]. Na wyróżnienie zasługują także prace R. Asplund oraz D. Carda. Autorka pierwszej z nich w swoich badaniach wyznaczyła rentowność z kształcenia na poziomie wyższym w Finlandii na poziomie od 7\% do 9,6\% dla lat 1984-1995. Ze względu na specyfikę wykorzystywanych informacji pochodzących z Finnish Labour Force Survey mogła wyznaczyć funkcję wynagrodzeń, wykorzystując potencjalne i rzeczywiste doświadczenie zawodowe. Otrzymane wyniki wskazały jednak na nieistotność takiej zamiany, potwierdzając tym samym pogląd zaprezentowany przez Mincera, iż doświadczenie potencjalne w sposób prawidłowy przybliża przyrost kapitału ludzkiego związanego z nabywaniem umiejętności przez pracę zawodową [Asplund 2000]. Druga z prac, autorstwa D. Carda, zasługuje na uwagę ze względu na to, iż autor jako jeden z niewielu wyznaczył rentowność dla inwestycji w wyższe wykształcenie w zależności od kierunku studiów (na poziomie od 6\% do 11\%) [Card 1999].

Osobne miejsce należy poświęcić badaniom przeprowadzonym pod patronatem Organizacji Współpracy Gospodarczej i Rozwoju (OECD), przede wszystkim ze względu na zastosowaną tam metodologię. Wykorzystano tam bardziej skomplikowane podejście eliminujące większość wad zwykłej metody Mincera, a zaproponowane po raz pierwszy przez A. De la Fuente oraz J.F. Jimeno. Polega ono na połączeniu funkcji wynagrodzeń Mincera z miernikami oceny opłacalności inwestycji wykorzystywanymi w zarządzaniu finansami przedsiębiorstw. Funkcja wynagrodzeń jest konstruowana w standardowy sposób, czyli poziom wynagrodzeń jest uzależniany od okresu kształcenia (lub poziomu wykształcenia jak w metodzie zaproponowanej przez Lauera i Steinera), potencjalnego doświadczenia zawodowego oraz wybranych charakterystyk społeczno-demograficznych. Tak wyznaczoną funkcję wynagrodzeń można wykorzystać do wyliczenia przepływów finansowych niezbędnych do wyznaczenia np. wewnętrznej stopy zwrotu (IRR). Wykorzystanie IRR jako miernika rentowności inwestycji w wyższe wykształcenie pozwala uwzględnić dowolny zakres kosztów takiej inwestycji (oczywiście w zależności od dostępnych danych statystycznych) oraz zmiany wartości pieniądza w czasie, czyli wyeliminować główne zarzuty dotyczące czystej funkcji wynagrodzeń Mincera (zostały one opisane szczegółowo w dalszej części artykułu) [De la Fuente, Jimeno 2005]. We wspomnianym badaniu 
OECD, przeprowadzonym przez R. Boarini i H. Straussa, wykorzystano właśnie takie podejście, wyznaczając w ten sposób stopę zwrotu z inwestycji w wyższe wykształcenie dla 21 państw w latach 1991-2005. Z powodu jednak braku odpowiednich danych statystycznych badania dotyczące Polski zostały ograniczone jedynie do lat 1997-2001. Wyliczona stopa zwrotu z inwestycji w wyższe wykształcenie dla tych lat wahała się między $6,5 \%$ a $8,9 \%$ dla mężczyzn oraz między $9,2 \%$ a $11,8 \%$ dla kobiet [Boarini, Strauss 2007].

Należy również wymienić najważniejsze badania poświęcone rentowności kształcenia w Polsce, aby przedstawić, jakie metody dotychczas wykorzystano w Polsce oraz jakie otrzymano wyniki. Jednymi z bardziej cenionych są badania przeprowadzone przez J. Weisberga i M.W. Sochę, w których autorzy nie tylko oszacowali stopę zwrotu z kształcenia na poziomie 7-8\% za każdy dodatkowy rok edukacji, ale także wykazali, iż istotnym czynnikiem wpływającym na różnice w wynagrodzeniach osób $\mathrm{z}$ różnym poziomem wykształcenia jest $\mathrm{w}$ polskich warunkach sektor zatrudnienia (publiczny lub prywatny) [Weisberg, Socha 2002, s. 533-577]. Kolejnymi, na które warto zwrócić uwagę, są badania przeprowadzone przez P.A. Puhani, który oszacował, iż wynagrodzenia osób z wyższym wykształceniem w Polsce są o około $50 \%$ wyższe niż pozostałych zatrudnionych, wskazując także, że istotnym czynnikiem wpływającym na zróżnicowanie tych wynagrodzeń jest wiek, a tym samym potencjalny staż pracy [Puhani 2000]. Podobne wnioski zostały dostrzeżone przez S. Roszkowską oraz A. Roguta, którzy na podstawie danych z publikacji GUS-u Struktura wynagrodzeń wedtug zawodów dla lat 2001 i 2004 wyznaczyli premię za wyższe wykształcenie w postaci wyższych wynagrodzeń na poziomie około $30-50 \%$ przeciętnego wynagrodzenia, a także wykazali, iż pracownicy z 20-letnim stażem zarabiają o około 5-8\% więcej, niż wynosi średnia płaca, a z mniej niż rocznym stażem pracy około $30 \%$ mniej niż średnie wynagrodzenie [Roszkowska, Rogut 2007, s. 55-81].

Problem oszacowania stopy zwrotu z inwestowania w wyższe wykształcenie został także podjęty w ramach badania „Diagnoza społeczna. Warunki i jakość życia Polaków”. W ramach tego badania wyznaczona została jednak wyłącznie niezdyskontowana stopa zwrotu za cały okres aktywności zawodowej. Z tego wynika znacznie zawyżony otrzymany wynik - otrzymana stopa zwrotu dla studiów magisterskich wyniosła 57\% w roku 2009 oraz 41\% w roku 2011 [Czapiński, Sułek, Szumlicz 2011, s. 195-198]. Na podstawie uzasadnienia przedstawionego w dalszej części artykułu trzeba jednak uznać, iż zastosowanie niezdyskontowanych metod do oceny rentowności inwestycji o tak długim horyzoncie czasowym jest w zasadzie bezcelowe.

Ze względu na zastosowaną metodologię warto także wspomnieć o badaniach przeprowadzonych przez P. Strawińskiego oraz W. Jareckiego. Wykorzystali oni po części podejście zaproponowane przez De la Fuente i Jimeno, czyli najpierw wyznaczyli funkcję wynagrodzeń w zależności od wybranych czynników, a następnie na jej podstawie wyznaczyli stopę zwrotu z inwestycji w wyższe wykształcenie, uwzględniając wybrane koszty i stopę dyskontową. Prace P. Strawińskiego oparte były na danych pochodzących z opracowań GUS-u Struktura wynagrodzeń wedtug 
zawodów oraz Badanie budżetów gospodarstw domowych z lat 1998-2004. Wyznaczona funkcja wynagrodzeń uwzględniała m.in. geograficzny region zatrudnienia, a wyliczona roczna stopa zwrotu z wykształcenia wyższego kształtowała się na poziomie 5,4-9,3\% - w zależności od roku badania [Strawiński 2006]. Najnowszym opublikowanym badaniem jest praca przedstawiona przez W. Jareckiego, który podjął się szacowania rentowności inwestycji w wyższe wykształcenie ekonomiczne na podstawie przeprowadzonego przez siebie badania ankietowego wśród studentów i absolwentów studiów ekonomicznych w województwie zachodniopomorskim. Funkcja wynagrodzeń skonstruowana przez niego miała odmienną postać od tej zaproponowanej przez Mincera i uwzględniała odpowiedzi udzielone przez respondentów w autorskim badaniu ankietowym. Poziom wynagrodzeń uzależniono w niej od potencjalnego doświadczenia zawodowego, płci, zainteresowań osób podejmujących studia, przyczyn wyboru kierunku studiów oraz oceny otrzymanej na końcowym dyplomie studiów. Na podstawie w ten sposób wyznaczonej funkcji wynagrodzeń autor oszacował wewnętrzną stopę zwrotu (IRR) z takiej inwestycji. Ze względu na zakres posiadanych danych oraz specyfikę skonstruowanej funkcji wynagrodzeń do wyliczeń IRR przyjęto okres 11 lat po ukończeniu studiów, a nie cały okres pracy zawodowej aż do emerytury jak w innych tego typu badaniach. Oszacowana wewnętrzna stopa zwrotu była na poziomie 14-31\% dla absolwentów studiów stacjonarnych oraz 28$-50 \%$ dla absolwentów studiów niestacjonarnych [Jarecki 2011].

\subsection{Ograniczenia i krytyka funkcji wynagrodzeń}

Jak zaznaczono we wcześniejszej części artykułu, przy opisie poszczególnych badań nad rentownością kształcenia przy wykorzystaniu funkcji Mincera i jej modyfikacji, metody te nie są pozbawione wad. Pomimo tych ograniczeń metody te należą do najczęściej wykorzystywanych do szacowania wpływu wykształcenia na osiągane wynagrodzenie. Większość z tych niedociągnięć można oczywiście wyeliminować, pod warunkiem dostępu do odpowiednich danych statystycznych.

Do najistotniejszych wad oryginalnej funkcji Mincera należy nierozróżnianie poziomów edukacji, a jedynie uwzględnianie lat kształcenia. Powoduje to, że tak wyznaczona funkcja wynagrodzeń szacuje, iż każdy rok kształcenia daje taki sam przyrost płac. Wynikałoby z tego, że taki sam przyrost wiedzy i umiejętności zawodowych następuje po dodatkowym roku nauki w szkole podstawowej jak po dodatkowym roku studiów. Jest to oczywiście założenie nieprawdziwe. Dodatkowo taka konstrukcja funkcji wynagrodzeń może prowadzić do jeszcze większych zaburzeń. $\mathrm{Z}$ taką sytuacją będziemy mieli do czynienia np. w przypadku, gdy w badaniu będą brały udział osoby, które powtarzały ten sam rok nauki lub nie ukończyły ostatniego z rozpoczętych poziomów edukacji. Pomimo stosunkowo długiego okresu kształcenia tych osób, ich zasób wiedzy i umiejętności, a także poziom wykształcenia, jakim mogą się legitymować, jest niższy niż osób, których edukacja przebiegała bez zakłóceń. Oczywiste wydaje się więc, że zarobki tej pierwszej grupy powinny być niższe niż tej drugiej. Tym samym oszacowana w ten sposób funkcja wynagrodzeń będzie zaniżać 
rzeczywisty wzrost wynagrodzeń w zależności od długości kształcenia. Sposobem na uniknięcie tego błędu jest wykorzystanie w badaniach modyfikacji zaproponowanej przez Lauera i Steinera, którzy lata kształcenia zastąpili poziomami wykształcenia.

Kolejne zastrzeżenie dotyczy faktu, iż funkcja wynagrodzeń Mincera może być skutecznie wykorzystywana do badania wpływu wykształcenia, doświadczenia zawodowego oraz innych czynników społeczno-demograficznych na wysokość uzyskiwanych wynagrodzeń, ale de facto nie pozwala oszacować samej rentowności kształcenia. Przyczyną tego jest pomijanie w ten sposób kosztów zdobycia tego wykształcenia (pośrednich i bezpośrednich), które mają zdecydowany wpływ na osiąganą stopę zwrotu z takiej inwestycji. Konsekwencją może być zawyżenie tej rentowności przez współczynnik stojący przy zmiennej lata kształcenia czy poziomy wykształcenia w zmodyfikowanej formie funkcji Mincera. Wydaje się więc uzasadnione wprowadzenie rozwiązania zaproponowanego przez De la Fuente i Jimeno, którzy wykorzystali równanie Mincera do oszacowania jedynie przepływów pieniężnych, a w ten sposób pozyskane informacje użyli do szacowania rentowności przy użyciu mierników oceny opłacalności inwestycji pochodzących z obszaru wiedzy zarządzania finansami przedsiębiorstw. Takie podejście umożliwia uwzględnienie wybranych kosztów uzyskania określonego poziomu wykształcenia, oczywiście w zależności od dostępnych danych statystycznych.

Zastosowanie narzędzi z zakresu analizy finansowej pozwala także wyeliminować kolejny z zarzutów stawianych metodzie zaproponowanej przez J. Mincera, a mianowicie nieuwzględnianie przez nią zmiennej wartości pieniądza w czasie. Równanie Mincera oraz większość jego modyfikacji traktuje w identyczny sposób wszystkie nakłady i efekty kształcenia, pomimo że są one ponoszone lub osiągane w różnych okresach (latach). Ponieważ inwestycja w wykształcenie jest zdecydowanie inwestycją długoterminową, w której koszty ponoszone są przez cały okres kształcenia, a efekty osiągane dopiero po ukończeniu edukacji przez cały okres pracy zawodowej, porównanie nakładów i efektów nie powinno następować w taki sposób, jakby występowały one dokładnie w tym samym czasie. Zgodnie z teorią wartości pieniądza w czasie, która twierdzi, iż przepływy pieniężne zrealizowane w późniejszym okresie mają mniejszą wartość niż obecne, zawyżałoby to szacunki rentowności inwestycji w wyższe wykształcenie. Wykorzystanie mierników dyskontowych pozwoli wyeliminować tę wadę, co zostanie dokładniej uzasadnione w dalszej części artykułu.

Problemem, który zdecydowanie najtrudniej jest wyeliminować ze względu na brak dostępnych danych statystycznych, jest nieuwzględnianie w szacunkach rentowności kierunków kształcenia. Na przykład kierunek studiów wyższych w zdecydowany sposób wpływa na to, jaki zawód może w przyszłości wykonywać dana osoba, a tym samym na wysokość osiąganego przez nią wynagrodzenia. W polskich warunkach zdecydowanie wyższe wynagrodzenia osiągają osoby po kierunkach politechnicznych, medycynie czy prawie w stosunku do osób po kierunkach np. pedagogicznych. $Z$ tego wynika, że prawdopodobne jest otrzymanie znacznych różnic przy szacowaniu rentowności wyższego wykształcenia osobno dla każdego kierunku studiów, a oszacowana 
rentowność łącznie dla wszystkich absolwentów będzie dla jednych zaniżała, a dla innych zawyżała ich rzeczywistą stopę zwrotu. Ponieważ jednak wyeliminowanie tego problemu wymagałoby posiadania danych statystycznych, gdzie oprócz poziomów wykształcenia znajdowałyby się także informacje o jego kierunku (a tak naprawdę także o tym, czy dana osoba pracuje w zawodzie zgodnym ze swoim wykształceniem), W większości przeprowadzonych na świecie badań ten aspekt był pomijany. Istnieją jedynie pojedyncze badania, w których przy szacowaniu rentowności uwzględniono kierunki kształcenia, najczęściej jednak dane w nich wykorzystywane pochodziły z badań ankietowych, których zakres uniemożliwiał uwzględnienie innych istotnych informacji (np. doświadczenia zawodowego czy ryzyka bezrobocia, a także większości kosztów bezpośrednich lub pośrednich inwestycji w wyższe wykształcenie) [Parmentier, Scheda, Schreyer 1998; Ederer, Kopf, Schuller, Ziegele 2000; Rumberger, Thomas 1993 oraz Battu, Balfield, Sloane 1999].

\section{Metody szacowania okresu i stopy zwrotu $z$ indywidualnych inwestycji w ksztalcenie}

\subsection{Metody szacowania okresu zwrotu $\mathrm{z}$ indywidualnych inwestycji w kształcenie}

Okres zwrotu z inwestycji przedstawia czas (wyrażony w miesiącach lub latach), po którym zwrócą się nakłady poniesione na daną inwestycję, czyli osiągnięte przychody pokryją koszt inwestycji. Jest to pierwsza formalna metoda, która była wykorzystywana do oceny projektów inwestycyjnych [Sierpińska, Jachna 1998, s. 197]. Jej zaletą jest niewątpliwie prostota wyznaczania oraz interpretacji okresu zwrotu, choć jej zastosowanie przy wyborze spomiędzy różnych projektów inwestycyjnych jest bardzo ograniczone. Wada ta nie ma jednak znaczenia w przypadku, gdzie przy wykorzystaniu tej metody ma zostać wyznaczony okres zwrotu z tylko jednej możliwej inwestycji (w tym przypadku inwestycji w kształcenie). Dodatkowo w przypadku inwestycji w kształcenie informacja o okresie zwrotu może być bardziej czytelna i przydatna dla osób pragnących w przyszłości podjąć studia niż stopa zwrotu. Jako pierwszy badania dotyczące okresu zwrotu z inwestycji w kształcenie (a dokładniej prostego okresu zwrotu) prowadził T.W. Schultz, później jednak metoda ta była stosunkowo rzadko wykorzystywana [Jarecki 2011, s. 153].

Należy tu wspomnieć także o badaniach nad okresem zwrotu z inwestycji w wyższe wykształcenie w Polsce przeprowadzonych przez P. Strawińskiego i W. Jareckiego. Pierwszy z nich wyznaczył okres zwrotu z takiej inwestycji, przyjmując, że będzie ona finansowana $z$ kredytu studenckiego. Rozpatrzył także dwa modele spłaty takiego kredytu - ,premia” oraz „minimum”. W pierwszym z nich przyjął założenie, że osoba z wykształceniem wyższym na spłatę kredytu przeznacza jedynie nadwyżkę swojego dochodu nad wynagrodzenie hipotetycznej osoby z wykształceniem średnim. Okres spłaty kredytu wyniósł wtedy od 11 do 25 lat - w zależności od przyjętej wartości 
stopy procentowej (od 1\% do 10\%). W wariancie „minimum” przyjęto założenie, iż na spłatę kredytu przeznaczana jest nadwyżka dochodu powyżej minimum socjalnego. Okres spłaty kredytu w tym wariancie wyniósł wtedy od 6 do prawie 9 lat w zależności od wysokości oprocentowania kredytu. Drugi wariant należy przy tym uznać za mało prawdopodobny, gdyż wymaga, aby osoba po ukończeniu studiów na ponad 6 lat ograniczyła swoją konsumpcję do minimalnego poziomu zaspokajającego jej potrzeby biologiczne, kulturalne i społeczne [Strawiński 2006, s. 17-18]. W. Jarecki w swoich badaniach zajął się wyznaczeniem prostego i zdyskontowanego okresu zwrotu z inwestycji w kształcenie ekonomiczne na poziomie wyższym dla województwa zachodniopomorskiego. Za stopę dyskonta przyjął średnie oprocentowanie czteroi dziesięcioletnich obligacji Skarbu Państwa. Wyznaczony prosty okres zwrotu mieścił się w przedziale od 1,4 do 6,3 roku, w zależności od trybu studiowania i stanowiska pracy, a zdyskontowany w przedziale od 1,7 do 7,5 - w zależności od tych samych parametrów [Jarecki 2011, s. 237-252].

W analizie oceny efektywności przedsięwzięć inwestycyjnych wykorzystywany jest prosty okres zwrotu (PB - Payback Period) oraz zdyskontowany okres zwrotu (DPB - Discounted Payback Period). Miary te różnią się od siebie jedynie tym, że w PB uwzględnia się wartości nominalne przepływów pieniężnych, a w DPB wartości zdyskontowane, czyli skorygowane o zmianę wartości pieniądza w czasie [Michalski 2010, s.72].

Wartość pieniądza, który znajdzie się w czyjejś dyspozycji, zależy od czasu, kiedy zostanie on otrzymany. Im później dana kwota zostanie uzyskana, tym jej bieżąca wartość jest mniejsza. Wynika to z odmiennej dyspozycyjności pieniądza posiadanego obecnie w stosunku do pieniądza, który uzyskamy dopiero w przyszłości. Pieniądz, który otrzymamy dopiero w przyszłości, można określić jako „zamrożony”, gdyż nie można go wykorzystać w celach konsumpcyjnych bądź inwestycyjnych [Sierpińska, Jachna 2007, s. 11]. Jeżeli posiadalibyśmy go w chwili obecnej, mógłby nam pozwolić na osiągnięcie zysków (np. w postaci odsetek od zainwestowanego kapitału) lub moglibyśmy go użyć w celu zaspokojenia bieżących potrzeb konsumpcyjnych [Duraj 1996, s. 35-36]. Im dłuższy będzie więc okres zamrożenia, tym później będzie można tym pieniądzem swobodnie dysponować i niższa będzie jego aktualna wartość. Szczególnie istotne jest w takim razie uwzględnienie zmiany wartości pieniądza w czasie w przypadku inwestycji długoterminowych, a taką jest niewątpliwie inwestycja w kształcenie. Nakłady związane $\mathrm{z}$ tą inwestycją są bowiem ponoszone przez okres edukacji (np. studiów), a efekty w postaci wyższych wynagrodzeń w stosunku do osób z niższym poziomem wykształcenia występują przez cały okres pracy zawodowej (a nawet później w postaci wyższych emerytur), czyli kilkadziesiąt lat. $\mathrm{Z}$ tego względu do szacowania okresu zwrotu $\mathrm{z}$ inwestycji w kształcenie powinno się korzystać ze zdyskontowanego, a nie prostego okresu zwrotu.

Aby wyznaczyć zdyskontowany okres zwrotu z inwestycji w wyższe wykształcenie, należy najpierw wyliczyć nakłady poniesione na studia w każdym z lat (w zależności od przyjętych założeń, uwzględniając koszty bezpośrednie, pośrednie oraz 
koszt alternatywny utraconych wynagrodzeń), a także wykorzystując funkcję wynagrodzeń, należy wyznaczyć nominalne wynagrodzenia netto osób z wyższym i średnim wykształceniem. Nadwyżka wynagrodzeń osób z wyższym wykształceniem ponad wynagrodzenia osób z wykształceniem średnim będzie w każdym z lat stanowiła dodatni przepływ finansowy, który można określić jako efekt studiowania.

Zdyskontowany okres zwrotu z inwestycji w wyższe wykształcenie można wyznaczyć z następującego wzoru [Jarecki 2011, s. 154]:

$$
\sum_{n=0}^{N} \frac{-K n}{(1+r)^{n}}+\frac{W w n-W s n}{(1+r)^{n}} \geqslant 0
$$

gdzie:

$W w n$ - roczne wynagrodzenie netto osób z wyższym wykształceniem (przyjmuje wartości większe od 0 dla $n>4$, czyli po ukończeniu studiów;

Wsn - roczne wynagrodzenie netto osób ze średnim wykształceniem;

Kn - uwzględniony w badaniu koszt danego roku studiów (przyjmuje wartości większe od 0 dla $n<5$, czyli do czasu ukończenia studiów);

$r \quad$ - przyjęta stopa dyskontowa.

Długość zdyskontowanego okresu zwrotu z tego wzoru wyznacza się jako minimalną wartość parametru $n$, dla której spełniony będzie powyższy warunek. Koszt studiów $(K n)$ przyjmuje wartość większą od 0 jedynie przez pierwsze 5 lat inwestycji (studiów), natomiast w tym samym czasie wynagrodzenie netto osób z wykształceniem średnim (Wsn) stanowi koszt alternatywny (utracone wynagrodzenia) inwestycji w wyższe wykształcenie. Można też zauważyć, iż przyjmując za stopę dyskontową (r) wartość 0 , otrzyma się wzór na prosty okres zwrotu. Przy szacowaniu zdyskontowanego okresu zwrotu z inwestycji w kształcenie powstaje problem ustalenia wysokości stopy dyskontowej. Oceniając tradycyjne projekty inwestycyjne, jako stopę dyskontową przyjmuje się najczęściej koszt kapitału potrzebnego do sfinansowania takiej inwestycji lub stopę zwrotu $\mathrm{z}$ alternatywnej inwestycji o podobnym ryzyku. Ponieważ przy inwestycji w wyższe wykształcenie niemożliwe jest uzyskanie takich informacji, za stopę dyskontową przyjmuje się najczęściej oprocentowanie obligacji skarbowych jako alternatywnej inwestycji wolnej od ryzyka [Jarecki 2011, s. 238].

\subsection{Metody szacowania stopy zwrotu $\mathrm{z}$ indywidualnych inwestycji w kształcenie}

Miarą, która może być wykorzystana od oszacowania stopy zwrotu z inwestycji w wyższe wykształcenie, jest wewnętrzna stopa zwrotu (IRR - Internal Rate of Return). Należy wtedy skorzystać z metody zaproponowanej przez De la Fuente i Jimeno, w której do wyznaczenia przepływów finansowych w kolejnych latach wykorzystuje się wyznaczoną wcześniej funkcję wynagrodzeń J. Mincera lub jej modyfikację [De la Fuente, Jimeno 2005]. Takie rozwiązanie zostało przyjęte choćby w opisanych wcześniej badaniach prowadzonych na zlecenie OECD lub W. Jarec- 
kiego. Niewątpliwą zaletą takiego rozwiązania jest brak konieczności arbitralnego przyjmowania wartości stopy dyskontowej, choć, jak zostanie to pokazane w dalszej części artykułu, wewnętrzna stopa zwrotu ma także pewne wady, których nie da się wyeliminować.

Wewnętrzną stopę zwrotu można zdefiniować jako taką stopę procentową, przy której obecna wartość nakładów na daną inwestycję jest równa obecnej wartości wpływów z danej inwestycji. Innymi słowy jest to taka wysokość stopy dyskontowej, przy której wartość bieżąca netto (NPV) danej inwestycji jest równa 0 [Brigham, Houston 2005, s. 65].

Wartość IRR dla inwestycji w wyższe wykształcenie można wyznaczyć z następującego wzoru:

$$
\sum_{n=0}^{N} \frac{W w n-W S n-K n}{(1+I R R)^{n}}=0
$$

gdzie:

$W w n$ - roczne wynagrodzenie netto osób z wyższym wykształceniem (przyjmuje wartości większe od 0 dla $n>4$, czyli po ukończeniu studiów);

Wsn - roczne wynagrodzenie netto osób ze średnim wykształceniem;

Kn - uwzględniony w badaniu koszt danego roku studiów (przyjmuje wartości większe od 0 dla $n<5$, czyli do czasu ukończenia studiów);

$I R R$ - szacowana rentowność w postaci wewnętrznej stopy zwrotu.

Koszt studiów $(K n)$ przyjmuje wtedy wartości większe od zera jedynie w ciągu trwania edukacji (np. 5 lat), a wynagrodzenia netto osób z wyższym wykształceniem ( $W w n$ ) zaczynają przyjmować wartości większe od 0 dopiero po ukończeniu studiów, czyli po rozpoczęciu pracy zawodowej.

Wewnętrzna stopa zwrotu bezpośrednio mówi o tym, jaką średnią roczną stopę rentowności miała dana inwestycja, czyli odzwierciedla roczną stopę zwrotu z poniesionych nakładów. Im wyższą wartość przyjmuje IRR, tym większy dochód przynosi inwestycja, czyli jest bardziej rentowna. Przy zastosowaniu wewnętrznej stopy zwrotu do oceny rentowności inwestycji w wyższe wykształcenie można ją zinterpretować jako roczną stopę zwrotu, którą osoba z wykształceniem średnim musiałaby uzyskać ze środków zaoszczędzonych dzięki niepodjęciu studiów, aby zdyskontowanym poziomem zamożności dorównać osobie $\mathrm{z}$ wykształceniem wyższym [Adamczyk 2008, s. 84].

Przy wyznaczaniu wewnętrznej stopy zwrotu dla inwestycji podejmowanych przez przedsiębiorstwa mogą pojawić się problemy, jeżeli przepływy finansowe są rozłożone niekonwencjonalnie, to znaczy występują ujemne przepływy finansowe (nakłady) nie tylko na początku trwania inwestycji, ale także w późniejszym okresie. Możliwe jest wtedy wystąpienie więcej niż jednej lub żadnej IRR, co sprawia, że metoda ta jest wtedy nieużyteczna przy porównaniu opłacalności inwestycji [Michalski 2010]. W przypadku inwestycji w wyższe wykształcenie ta wada jest jednak nieistotna, gdyż przepływy finansowe mają konwencjonalny układ (koszty ponoszone są jedynie na początku), więc zawsze będzie możliwe wyznaczenie tylko jednej wewnętrznej stopy zwrotu. 


\section{Zakończenie}

Na podstawie informacji opisanych w poprzednich częściach artykułu można dojść do wniosku, że najlepszą metodą badań wpływu wykształcenia na wynagrodzenia oraz rentowności inwestycji w wyższe wykształcenie jest metoda zaproponowana przez De la Fuente oraz Jimeno, czyli połączenie funkcji wynagrodzeń i mierników używanych w zarządzaniu finansami przedsiębiorstw.

Oryginalna funkcja wynagrodzeń Mincera wydaje się przy tym niewłaściwa, gdyż uwzględnia jedynie lata kształcenia, pomijając poziomy wykształcenia, co może prowadzić do problemów opisanych wcześniej. Uzasadnione wydaje się więc zastąpienie jej modyfikacją zaproponowaną przez Lauera i Steinera, wprowadzając rozróżnienie na poziomy wykształcenia zamiast lat edukacji. Dodatkowo warto tę funkcję rozbudować w taki sposób, aby uwzględnić inne istotne czynniki wpływające na wysokość wynagrodzeń w Polsce, co pozwoli nie tylko dokładniej oszacować wpływ poszczególnych czynników na wynagrodzenia, ale także wyliczyć rentowność z inwestycji w wyższe wykształcenie osobno dla każdej podgrupy próby badawczej. Na podstawie analizy dotychczasowych badań przeprowadzonych w tym zakresie oraz ze względu na dostępność danych statystycznych uzasadnione jest rozbudowanie funkcji wynagrodzeń o zmienne dotyczące płci, wielkości miejsca zamieszkania oraz sektora zatrudnienia (uwzględniając tu podział na osoby pracujące w sektorze publicznym, prywatnym oraz jako przedsiębiorcy).

Funkcja wynagrodzeń potrafi pokazać wpływ wykształcenia na osiągane wynagrodzenie, ale de facto nie wyznacza rentowności z samej inwestycji w wykształcenie, uzasadnione jest więc wykorzystanie mierników z zakresu zarządzania finansami przedsiębiorstw do oszacowania okresu i stopy zwrotu $\mathrm{z}$ inwestycji w wyższe wykształcenie. $Z$ powodów opisanych we wcześniejszej części artykułu konieczne jest użycie do tego miar zdyskontowanych z pominięciem przy tym metod prostych, nieuwzględniających zmian wartości pieniądza w czasie.

Oszacowanie okresu zwrotu z inwestycji w wyższe wykształcenie w Polsce będzie więc możliwe dzięki wykorzystaniu zdyskontowanego okresu zwrotu (DPB), jeśli jako stopę dyskontową przyjmie się rentowność obligacji skarbowych w danym okresie. Uzasadnione wydaje się także przeprowadzenie analizy wrażliwości okresu zwrotu w zależności od przyjętej stopy dyskontowej.

W dotychczasowych badaniach nad rentownością kształcenia do wyznaczania stopy zwrotu z inwestycji w kształcenie najczęściej używaną miarą była wewnętrzna stopa zwrotu (IRR). Pozwala ona uwzględnić dowolny zakres kosztów inwestycji w kształcenie oraz oszacować średnią roczną stopę zwrotu z takiej inwestycji.

Metoda wewnętrznej stopy zwrotu ma jednak pewną wadę, szczególnie istotną przy wykorzystaniu jej do określania rentowności kształcenia. Zakłada ona bowiem, iż dodatnie przepływy pieniężne uzyskane $\mathrm{z}$ danej inwestycji będą reinwestowane po stopie zwrotu równej IRR. Jest to założenie mało realne, gdyż wymaga, aby było możliwe reinwestowanie przepływów finansowych w przedsięwzięcie o identycznej 
rentowności jak inwestycja, dla której wyznaczana była wewnętrzna stopa zwrotu. Może być to mało prawdopodobne, gdy wewnętrzna stopa zwrotu jest stosunkowo wysoka, co może uniemożliwić znalezienie w przyszłości inwestycji o tak wysokiej rentowności [Szczepański i Szyszko (red.) 2007, s. 423]. Założenie o stopie reinwestycji równej IRR jest całkowicie niemożliwe do spełnienia w przypadku inwestycji w kształcenie. Niemożliwe jest bowiem po uzyskaniu danego poziomu wykształcenia rozpoczęcie kolejnego etapu edukacji, który przyniósłby identyczną stopę zwrotu lub znalezienie innej inwestycji z taką samą rentownością. Jest to spowodowane unikatowością efektów uzyskiwanych przy inwestycji w kształcenie. Miarą, która eliminuje ten problem, jest zmodyfikowana wewnętrzna stopa zwrotu (MIRR - Modified Internal Rate of Return).

Modyfikacja wewnętrznej stopy zwrotu w tym mierniku polega na wyeliminowaniu założenia, że stopa reinwestycji jest równa IRR, i przyjęciu w zamian z góry założonej stopy reinwestycji. Najczęściej stosowanym rozwiązaniem jest przyjęcie jej w wysokości odpowiadającej kosztowi kapitału dla danej inwestycji, co w przypadku inwestycji w kształcenie jest niemożliwe. Uzasadnione wydaje się więc przyjęcie w tym wypadku identycznej stopy reinwestycji jak przyjęta wcześniej stopa dyskonta, czyli odpowiadającej oprocentowaniu obligacji skarbowych. Wartość zmodyfikowanej wewnętrznej stopy zwrotu dla inwestycji w wyższe wykształcenie można wtedy wyznaczyć z następującego wzoru (opracowanie własne na podstawie [Michalski 2010, s. 98]):

$$
M I R R=\sqrt[N]{\frac{\sum_{n=5}^{N}(W w n-W s n) \times(1+r)^{(N-n)}}{\sum_{n=0}^{4} \frac{K n+W S n}{(1+r)^{n}}}}-1,
$$

gdzie:

$M I R R$ - wartość zmodyfikowanej wewnętrznej stopy zwrotu dla inwestycji w wyższe wykształcenie;

$(W w n-W s n)$ - efekt wyższego wykształcenia w postaci nadwyżki wynagrodzenia ponad wynagrodzenie osoby z wykształceniem średnim (przepływ dodatni);

Wsn - roczne wynagrodzenie netto osób ze średnim wykształceniem;

Kn - uwzględniony w badaniu koszt danego roku studiów;

$r \quad$ - stopa dyskonta i reinwestycji.

MIRR przedstawia średnią roczną stopę zwrotu z inwestycji przy założeniu, że dodatnie przepływy pieniężne są reinwestowane po stopie procentowej odpowiadającej stopie dyskonta. W przypadku inwestycji w wyższe wykształcenie oznacza to, iż dodatnie przepływy pieniężne pochodzące $z$ tej inwestycji, czyli nadwyżka wynagrodzenia osoby z wyższym wykształceniem ponad wynagrodzenie osoby z wykształceniem średnim, będą reinwestowane przy rentowności odpowiadającej oprocentowaniu obligacji skarbowych, czyli inwestycji wolnej od ryzyka. Jest to założenie bardziej 
uzasadnione od tego przyjętego przy obliczaniu IRR, które zakładało przyjęcie jako stopy reinwestycji stopy zwrotu $\mathrm{z}$ inwestycji w wyższe wykształcenie. Zastosowanie zmodyfikowanej wewnętrznej stopy zwrotu do oszacowania rentowności inwestycji w wyższe wykształcenie wprowadza nową jakość w ten obszar badawczy, gdyż metoda ta nie była do tej pory stosowana do wyznaczania stopy zwrotu z inwestycji w kształcenie, a zdaniem autora wydaje się najbardziej do tego odpowiednia.

Analiza rentowności inwestycji w wyższe wykształcenie może również zostać uzupełniona o dwa dotychczas rzadko stosowane w tego typu badaniach mierniki, mianowicie wartość zaktualizowaną netto (NPV - Net Present Value) oraz indeks zyskowności (PI - Profitability Index).

NPV odpowiada obecnej wartości wpływów i nakładów pieniężnych związanych $z$ daną inwestycją. Jest jednym z podstawowych i najczęściej stosowanych kryteriów oceny opłacalności inwestycji. Wartość zaktualizowana netto uwzględnia wpływ czasu na wartość pieniądza, a więc informuje w bezpośredni sposób, jakie zaktualizowane korzyści może przynieść określona inwestycja. Dodatnia wartość NPV oznacza, że stopa zwrotu z inwestycji jest wyższa od przyjętej stopy dyskontowej $(r)$, a ewentualne zwiększenie stopy dyskonta przy konwencjonalnych przepływach pieniężnych zmniejszyłoby wysokość NPV. Wartość zaktualizowana netto zakłada, iż uzyskiwane przepływy dodatnie są reinwestowane ze stopą zwrotu równą stopie dyskonta (w przypadku inwestycji w wyższe wykształcenie należy za nią przyjąć oprocentowanie obligacji skarbowych) [Michalski 2010, s. 75-77]. Nie istnieje więc konieczność modyfikacji NPV w taki sposób, w jaki miało to miejsce w przypadku IRR. Istnieje też ścisłe powiązanie między wartością zaktualizowaną netto a wewnętrzną stopą zwrotu - IRR odpowiada takiej stopie dyskonta, przy której wartość NPV wynosi dokładnie 0 .

Wartość zaktualizowaną netto dla inwestycji w wyższe wykształcenie można wyznaczyć, korzystając z następującego wzoru (opracowanie własne na podstawie [Brigham, Houston 2005, s. 63]):

$$
N P V=\frac{\sum_{n=0}^{N} W w n-W s n-K n}{(1+r)^{n}},
$$

gdzie:

$N P V$ - wartość zaktualizowana netto inwestycji w wyższe wykształcenie;

$W w n$ - roczne wynagrodzenie netto osób z wyższym wykształceniem (przyjmuje wartości większe od 0 dla $n>4$, czyli po ukończeniu studiów;

Wsn - roczne wynagrodzenie netto osób ze średnim wykształceniem;

Kn - uwzględniony w badaniu koszt danego roku studiów (przyjmuje wartości większe od 0 dla $n<5$, czyli do czasu ukończenia studiów);

$r \quad$ - stopa dyskonta i jednocześnie reinwestycji.

Indeks zyskowności (PI), w odróżnieniu od wartości zaktualizowanej netto, jest kryterium względnym. Informuje o tym, ile jednostek pieniężnych zostanie 
otrzymanych do końca trwania inwestycji w wyniku zainwestowania jednostki nakładu, czyli przedstawia efektowność inwestycji. Oblicza się go jako iloraz zdyskontowanych dodatnich przepływów pieniężnych w stosunku do zdyskontowanych przepływów ujemnych. Jeżeli PI dla przyjętej stopy dyskonta przyjmuje wartości większe od 1, oznacza to, że dana inwestycja jest opłacalna (zdyskontowane wpływy przekraczają zdyskontowane nakłady, czyli wartość NPV takiej inwestycji jest większa od 0). Jeżeli PI dla przyjętej stopy dyskonta przyjmuje wartości mniejsze od 1, oznacza to, że dana inwestycja nie jest opłacalna (zdyskontowane wpływy są mniejsze od zdyskontowanych nakładów, czyli wartość NPV takiej inwestycji jest mniejsza od 0) [Sierpińska, Jachna 2007, s. 480-482].

Indeks zyskowności, podobnie jak wartość zaktualizowana netto, zakłada, iż uzyskiwane przepływy dodatnie są reinwestowane ze stopą zwrotu równą stopie dyskonta, więc identycznie jak przy NPV nie występuje konieczność modyfikacji tego miernika na potrzeby przeprowadzania badań dotyczących rentowności inwestycji w wyższe wykształcenie. PI pozwala wyliczyć stopę zwrotu z całej inwestycji od początku do końca jej trwania (nie roczną jak było w przypadku IRR lub MIRR). Dla inwestycji w wyższe wykształcenie można byłoby ją interpretować jako stopę zwrotu (rentowność) zdobycia wyższego wykształcenia od momentu rozpoczęcia studiów do przejścia na emeryturę. Wartość indeksu zyskowności dla inwestycji w wyższe wykształcenie można wyznaczyć z następującego wzoru (opracowanie własne na podstawie [Michalski 2010, s. 86]):

$$
P I=\frac{\sum_{n=5}^{N} \frac{W w n-W s n}{(1+r)^{n}}}{\sum_{n=0}^{4} \frac{K n+W s n}{(1+r)^{n}}},
$$

gdzie:

$P I \quad$ - indeks zyskowności inwestycji w wyższe wykształcenie;

$(W w n-W s n)$ - efekt wyższego wykształcenia w postaci nadwyżki wynagrodzenia ponad wynagrodzenie osoby z wykształceniem średnim (przepływ dodatni); $W s n$ - roczne wynagrodzenie netto osób ze średnim wykształceniem;

$K n$ - uwzględniony w badaniu koszt danego roku studiów;

$r \quad$-stopa dyskonta i jednocześnie reinwestycji.

\section{Literatura}

Acemoglu D., Angrist J., 1999, How Large Are the Social Returns to Education? Evidence From Compulsory Schooling Laws, NBER Working Paper, nr 7444.

Adamczyk A., Jarecki W., 2008, Szacowanie wewnętrznej stopy zwrotu inwestycji w wyższe wyksztatcenie, Gospodarka Narodowa nr 11-12.

Ammermuller A., Dohmen D., 2004, Individuelle und soziale Ertrage von Bildungsinvestitionen, Studien zum deutschen Innovationssystem, nr 1, FiBS, Koln. 
Asplund R., 2000, Private returns to education in Finland: back to basics, Keskusteluaiheita - Discussion papers no. 720 , Helsinki.

Bar-Or Y., Burbidge J., Magee L., Robb A., 1995, The wage premium to a university education in Canada 1971-1991, Journal of Labour Economics, vol. 13, nr 4.

Battu H., Balfield C., Sloane P., 1999, Overeducation amog graduates: a cohort view, Education Economics no 7(1).

Boarini R., Strauss H., 2007, The Private Internal Rates of Return to Tertiary Education: New Estimates for 21 OECD Countries, Economics Department Working Papers, no. 591.

Brigham E.F., Houston J.F., 2005, Podstawy zarzadzania finansami, tom 2, PWE, Warszawa.

Card D., 1999, The Casual Effect of Education on Earnings, [w:] O. Ashenfelted, D. Card, Handbook of Labour Economics, North Holland.

Cichy K., Malaga K., 2007, Kapitat ludzki w modelach i teorii wzrostu gospodarczego, [w:] Kapital ludzki i kapitał społeczny a rozwój regionalny, red. M. Herbsta, Wydawnictwo Naukowe „Scholar", Warszawa.

Czapiński J., Sułek A., Szumlicz T., Indywidualna jakość życia. Diagnoza Społeczna 2011. Warunki i jakość życia Polaków - raport, Contemporary Economics, 5(3).

De la Fuente A., 2003, Human Capital in a Global and Knowledge-based Economy. Part 2: Assessment at the EU Country Level, Raport Komisji Europejskiej.

De la Fuente A., Jimeno J.F., 2005, The Private and Fiscal returns to Schooling and the Effect of Public Policies on Private Incentives to Invest in Education: A General Framework and Some Results for the EU, CESifo Working Paper, no. 1392.

Duraj J., 1996, Przedsiębiorstwo na rynku kapitałowym, PWE, Warszawa.

Harmon C., Oosterbeek H., Walter I., 2002, The Returns to Education: A Review of Evidence, Center for Economics of Education, London.

Jarecki W., 2011, Szacowanie kosztów i efektów kształcenia ekonomicznego na poziomie wyższym, Wydawnictwo Naukowe Uniwersytetu Szczecińskiego, Szczecin.

Kalpana P., 2008, The Impact of Educational Attainment on Labor Market Outcomes, Luxembourg Income Study Working Paper Series Working Paper No. 475.

Lauer C., Steiner V., 2001, Returns to Education in West Germany - An Empirical Assessment, ZEW, Discussion Paper No. 00-04/2001, Mannheim.

Michalski G., 2010, Wprowadzenie do zarządzania finansami przedsiębiorstw, Wydawnictwo C.H. Beck, Warszawa.

Mincer J., 1958, Investment in human capital and personal income distribution, Journal of Political Economy, vol. 66, no. 4.

Mincer J., 1974, Schooling, Experience and Earnings, Columbia University Press, New York-London.

Parmentier K., Scheda H.J., Schreyer F., 1998, Studium und Arbeitsmarkt im Ueberblick, Materiallen nr 1.7/1998, IAB, Bonn.

Psacharopoulos G., Patrinos H., 2002, Returns to Investment in Education: A Further Update, World Bank Policy Research Working Paper No. 2881.

Puhani P.A., On the Identification of Relative Wage Rigidility Dynamice. A Proposal for a Methodology on Cross-Section Data and Empirical Evodence for Poland in Transition, IZA Discussions Paper 2000, no. 226.

Roszkowska S., Rogut A., 2007, Rozkład płac i kapitału ludzkiego w Polsce, Gospodarka Narodowa, nr 11-12.

Rumberger R., Thomas S., 1993, The economic returns to college major, quality and performance: a multilevel analysis of recent graduates, Economic of Education Review, no. 12.

Schultz T.W., 1967, The rate of return in allocating investment resources to education, „Journal of Human Resources, no. 2.

Schultz T.W., 1971, Investment in Human Capital, The Free Press, New York. 
Sierpińska M., Jachna T., 1998, Ocena przedsiębiorstwa wedtug standardów światowych, Wydawnictwo Naukowe PWN, Warszawa.

Sierpińska M., Jachna T., 2007, Metody podejmowania decyzji finansowych. Analiza przykładów i przypadków, Wydawnictwo Naukowe PWN, Warszawa.

Strawiński P., 2006, Zwrot z inwestowania w wyższe wyksztatcenie, Ekonomista, nr 6.

Strawiński P., 2008, Opłacalność studiów w Polsce. Model i jego wyniki, Ekonomista, nr 4.

Szczepański J. i Szyszko L. (red.), 2007, Finanse przedsiębiorstwa, PWE, Warszawa.

Weisberg J., Socha M. W., 2002, Labor Market Transition in Poland: Changes in the Public Private Sectors, International Journal of Manpower, vol. 23, no. 6. 